\title{
Hijab fashion supply chain: a theoretical framework traversing consumers' knowledge and purchase intention
}

\author{
Eli Sumarliah",a ${ }^{1, T i e k e ~} \mathrm{Li}^{1}$ and Bailin Wang ${ }^{1}$ \\ ${ }^{1}$ Donlinks School of Economics and Management, University of Science and Technology Beijing, Xueyuan Road 30, Haidian, \\ Beijing, China
}

\begin{abstract}
The recent expeditious growth of Muslim population in the world initiates a dramatic upsurge of demand for Hijab fashion. Hijab fashion is a green and sustainable fashion in accordance with Islamic principles on the modesty, safety, cleanliness, and comfort of clothings. Hijab supply chain is an indispensable issue, predominantly for Muslim consumers, manufacturers, and suppliers that oblige global Muslim markets. Nonetheless, research on Hijab fashion is very limited. More specifically, although knowledge of products has a significant consequence on consumers' intention to buy Hijab, no preceding research have attempted to hypothesize the relationship between the knowledge dimensions of Hijab supply chain and consumer purchase intention. This paper attempts to propose an initial framework regarding Hijab purchase behavior. After an overall search of research articles directed in journal reference lists and electronic databases, the conceptual framework was created to hand out a set of propositions highlighting how to strengthen the link between consumers' knowledge dimensions and their intention to purchase Hijab. Recommendations for future research and strategies to boost the advantages for Hijab fashion suppliers, manufacturers, and marketers can be obtained from this model.
\end{abstract}

\section{Introduction}

Following numerous headlines about Hijab-wearing women making it into a beauty pageant in America and United Kingdom, New Zealand is the next to succeed. The actuality that an Indonesian-Malaysian bequest wearing Hijab, Nurul Shamsul, has made a history by being a Top 5 in Miss Universe New Zealand 2018 is an inescapable phenomenon indicating that Hijab fashion is not only a leading industry in Muslim populated countries but also an emerging market in Western nations. Islamic fashion has astonishingly achieved \$270 billion consumption worldwide in 2017 and been predicted to expand by 5 per cent to US $\$ 361$ billion by 2023 [1]. Lately the world's renowned fashion brands such as Alberta Ferretti, DKNY, Marks and Spencer, Max Mara and Nike have been operating to tap into the expedient market by producing Hijab fashion for Muslim-focused lines. Other eminent brands such as Dolce and Gabbana, H\&M, Carolina Herrera, Massimo Dutti, Macy's and Michael Kors have also created modest collections marketed just for Muslim women [1].

Hijab fashion is a green and sustainable fashion in accordance with Islamic principles on the modesty, safety, cleanliness, and comfort of clothings. Hijab fashion supply chain encompasses everything from the preparation and prosecution of Halal raw materials, e.g. fabrics or textiles which are less animal based, more plant based, and more sustainable to be manufactured, until the delivery of the final products to the customer in line with Sharia (Islamic law). Hijab fashion supply chain is an

\footnotetext{
${ }^{\mathrm{a}}$ Corresponding author: eliemulyadi@yahoo.co.id
}

essential issue, especially for Muslim consumers, manufacturers, and suppliers that accommodate Muslim markets. However, due to very limited studies on Hijab, the principles of the Hijab supply chain are still obscure. Further and more specifically, although consumer is a crucial part of supply chain, no conceptual framework and empirical evidence exist as to translating consumers' knowledge into their purchase intention regarding Hijab supply chain. Meanwhile, knowledge of products has a significant consequence on consumers' intention to buy, especially for new products [2]. Thus, it is presummed that knowledge of the Hijab fashion supply chain, e.g., what and how the products were manufactured, transported and distributed, will impact consumers' purchase intention of Hijab fashion products. Taking the issue into account, this paper ventures to propose an initial framework regarding Hijab fashion purchasing behavior.

\section{Methodology}

To design the theoretical framework of this study, an overall search of research articles was directed in journal reference lists and electronic databases. Forgoing research with interconnected topics were alienated into two groups. First, prior research that aimed at understanding the relationship between consumers' knowledge and the purchase intention of Islamic (Halal) products were identified. Second, preceding studies that 
aimed at understanding Hijab purchase intention using various independent variables were selected. The result shows that none of the first group of prior studies has explained Hijab fashion (as shown in Table 1) and none of preceding research related to Hijab fashion has used supply chain knowledge as independent variable (as shown in Table 2). Thus, this study sets a foundation for future research by creating an original conceptual framework bridging the relationship between customers' knowledge of Hijab fashion supply chain and their intention to purchase Hijab.

Table 1. Prior research on the links between knowledge and the purchase intention of Islamic products.

\begin{tabular}{|c|c|c|c|}
\hline Researchers & Year $^{1}$ & Product & Findings \\
\hline $\begin{array}{l}\text { Nurhayati } \\
\text { and Hendar } \\
\text { [3] }\end{array}$ & 2019 & $\begin{array}{l}\text { Halal } \\
\text { foods }\end{array}$ & $\begin{array}{l}\text { This study shows that } \\
\text { there is a relationship } \\
\text { between Halal product } \\
\text { knowledge and Halal } \\
\text { purchase intention. }\end{array}$ \\
\hline Haro [4] & 2018 & $\begin{array}{l}\text { Halal } \\
\text { cosmetics }\end{array}$ & $\begin{array}{l}\text { There are partially } \\
\text { positive and significant } \\
\text { influence between } \\
\text { knowledge towards } \\
\text { Halal cosmetics purchase } \\
\text { intention. }\end{array}$ \\
\hline $\begin{array}{l}\text { Briliana and } \\
\text { Mursito [5] }\end{array}$ & 2017 & $\begin{array}{c}\text { Halal } \\
\text { cosmetics }\end{array}$ & $\begin{array}{c}\text { Knowledge is } \\
\text { significantly related to } \\
\text { consumers' attitude } \\
\text { toward Halal cosmetics. }\end{array}$ \\
\hline $\begin{array}{l}\text { Maichum et } \\
\text { al [6] }\end{array}$ & 2017 & $\begin{array}{l}\text { Halal } \\
\text { foods }\end{array}$ & $\begin{array}{l}\text { Halal knowledge has a } \\
\text { significant effect on } \\
\text { attitude towards Halal } \\
\text { food and had no } \\
\text { significant effect on } \\
\text { Halal purchase intention. } \\
\text { It is due to the young } \\
\text { non-Muslim consumers } \\
\text { as respondents of the } \\
\text { research. } \\
\end{array}$ \\
\hline $\begin{array}{c}\text { Reni and } \\
\text { Ahmad [7] }\end{array}$ & 2016 & $\begin{array}{c}\text { Halal } \\
\text { banking }\end{array}$ & $\begin{array}{l}\text { The result shows that } \\
\text { knowledge is statistically } \\
\text { significant effect on } \\
\text { intention to select } \\
\text { Islamic bank in } \\
\text { Indonesia. }\end{array}$ \\
\hline $\begin{array}{c}\text { Yusoff et al } \\
{[8]}\end{array}$ & 2015 & $\begin{array}{l}\text { Halal } \\
\text { foods }\end{array}$ & $\begin{array}{l}\text { This study focused on } \\
\text { knowledge supply chains } \\
\text { and further identified } \\
\text { that knowledge has a } \\
\text { direct influence on } \\
\text { consumers' purchase } \\
\text { intention for Halal food } \\
\text { in Selangor, Malaysia. }\end{array}$ \\
\hline $\begin{array}{c}\text { Yunus et al } \\
{[9]}\end{array}$ & 2014 & $\begin{array}{l}\text { Halal } \\
\text { foods }\end{array}$ & $\begin{array}{l}\text { Halal awareness and } \\
\text { product ingredients have } \\
\text { significantly influenced } \\
\text { Muslim's intention to } \\
\text { buy Halal packaged food } \\
\text { that are produced by } \\
\text { Non-Muslim } \\
\text { manufacturers in } \\
\text { Malaysia. }\end{array}$ \\
\hline $\begin{array}{c}\text { Hamdan et al } \\
{[10]}\end{array}$ & 2013 & $\begin{array}{l}\text { Halal } \\
\text { foods }\end{array}$ & $\begin{array}{l}\text { There is a weak } \\
\text { relationship between }\end{array}$ \\
\hline
\end{tabular}

\begin{tabular}{|c|l|l|c|}
\hline & & Halal & $\begin{array}{c}\text { knowledge of Halal } \\
\text { foods and purchasing } \\
\text { decision. }\end{array}$ \\
\hline $\begin{array}{c}\text { Aziz and } \\
\text { Chok [11] }\end{array}$ & 2013 & $\begin{array}{c}\text { Knowledge concerning } \\
\text { Halal foods has positive } \\
\text { influence on attitudes } \\
\text { towards Halal foods. }\end{array}$ \\
\hline $\begin{array}{c}\text { Mukhtar and } \\
\text { Butt [12] }\end{array}$ & 2012 & $\begin{array}{c}\text { Halal } \\
\text { foods }\end{array}$ & $\begin{array}{c}\text { Consumers' knowledge } \\
\text { related to Halal foods } \\
\text { affects their intention to } \\
\text { choose Halal foods. }\end{array}$ \\
\hline
\end{tabular}

${ }^{1}$ Year of publication

Table 2. Synthesis of the determinants of purchase intentions of Hijab fashion products.

\begin{tabular}{|c|c|c|c|}
\hline Researchers & Year $^{1}$ & $\begin{array}{l}\text { Research } \\
\text { Society }\end{array}$ & Research Variables \\
\hline $\begin{array}{l}\text { Ali and } \\
\text { Sohail [13] }\end{array}$ & 2018 & $\begin{array}{l}\text { Pakistani } \\
\text { Hijabistas. }\end{array}$ & $\begin{array}{l}\text { Sources of fashion } \\
\text { information, fashion } \\
\text { motivation, fashion } \\
\text { uniqueness, fashion } \\
\text { consciousness, Hijab } \\
\text { buying behavior. }\end{array}$ \\
\hline $\begin{array}{l}\text { Rahma and } \\
\text { Aprianty } \\
{[14]}\end{array}$ & 2018 & $\begin{array}{l}\text { Indonesian } \\
\text { customers of } \\
\text { Ria Miranda } \\
\text { Hijab }\end{array}$ & $\begin{array}{l}\text { Brand image, fashion } \\
\text { consciousness, } \\
\text { purchase decision. }\end{array}$ \\
\hline $\begin{array}{l}\text { Wibowo and } \\
\text { Masitoh [15] }\end{array}$ & 2018 & $\begin{array}{l}\text { Indonesian } \\
\text { young } \\
\text { women. }\end{array}$ & $\begin{array}{ll}\text { Religiosity, } & \text { attitude, } \\
\text { Hijab } & \text { wearing } \\
\text { intention } & \\
\end{array}$ \\
\hline $\begin{array}{l}\text { Winahjoe } \\
\text { and Sutikno } \\
{[16]}\end{array}$ & 2018 & $\begin{array}{l}\text { Indonesian } \\
\text { Muslim } \\
\text { women not } \\
\text { wearing } \\
\text { Hijab. }\end{array}$ & $\begin{array}{lr}\text { Attitude, } & \text { subjective } \\
\text { norms, } & \text { perceived } \\
\text { personal } & \text { outcome, } \\
\text { perceived } & \text { behavioral } \\
\text { control, } & \text { purchase } \\
\text { intention. }\end{array}$ \\
\hline $\begin{array}{l}\text { Wibowo } \\
{[17]}\end{array}$ & 2017 & $\begin{array}{l}\text { Indonesian } \\
\text { Muslim } \\
\text { female } \\
\text { wearing } \\
\text { Hijab. }\end{array}$ & $\begin{array}{l}\text { Religiosity, } \\
\text { subjective norm, } \\
\text { attitude, Hijab } \\
\text { wearing intention. }\end{array}$ \\
\hline $\begin{array}{l}\text { Hasna and } \\
\text { Hati [18] }\end{array}$ & 2017 & $\begin{array}{l}\text { Muslim } \\
\text { women. }\end{array}$ & $\begin{array}{l}\text { Dressing style , } \\
\text { fashion } \\
\text { consciousness, } \\
\text { motivation, } \\
\text { uniqueness, Hijab } \\
\text { fashion consumption, } \\
\text { sources of fashion } \\
\text { knowledge, social } \\
\text { network sites. }\end{array}$ \\
\hline Fadhilla [19] & 2017 & $\begin{array}{l}\text { Customers of } \\
\text { two Hijab } \\
\text { companies in } \\
\text { Indonesia. }\end{array}$ & $\begin{array}{l}\text { Purchase intention, } \\
\text { marketing mix (price, } \\
\text { products, place, } \\
\text { promotion). }\end{array}$ \\
\hline $\begin{array}{l}\text { Zabeen et al } \\
{[20]}\end{array}$ & 2017 & $\begin{array}{l}\text { Bangladeshi } \\
\text { Hiab-wearing } \\
\text { women }\end{array}$ & $\begin{array}{lr}\text { Religious } & \text { duty, } \\
\text { beauty, influence of } \\
\text { opinion } & \text { leaders, } \\
\text { Hijab's } & \text { growing } \\
\text { popularity. }\end{array}$ \\
\hline $\begin{array}{l}\text { Hassan and } \\
\text { Harun [21] }\end{array}$ & 2016 & $\begin{array}{l}\text { Malaysian } \\
\text { Muslim } \\
\text { women. }\end{array}$ & $\begin{array}{l}\text { Dressing style , } \\
\text { fashion } \\
\text { consciousness, } \\
\text { motivation, } \\
\text { uniqueness, fashion } \\
\text { consumption, sources } \\
\text { of fashion } \\
\text { knowledge. }\end{array}$ \\
\hline
\end{tabular}




\begin{tabular}{|c|c|c|c|}
\hline $\begin{array}{l}\text { Win and Jan } \\
\text { [22] }\end{array}$ & 2016 & $\begin{array}{l}\text { Online } \\
\text { shopper in } \\
\text { Malaysia. }\end{array}$ & $\begin{array}{lr}\text { Online } & \text { purchase } \\
\text { intention, internal } \\
\text { influences, external } \\
\text { influences, online } \\
\text { shopping experience. }\end{array}$ \\
\hline $\begin{array}{l}\text { Nora and } \\
\text { Minarti [23] }\end{array}$ & 2016 & $\begin{array}{l}\text { Indonesian } \\
\text { female } \\
\text { students }\end{array}$ & $\begin{array}{l}\text { Religiosity, lifestyle, } \\
\text { attitude, purchase } \\
\text { intention }\end{array}$ \\
\hline $\begin{array}{l}\text { Grine and } \\
\text { Saeed [24] }\end{array}$ & 2015 & $\begin{array}{l}\text { Hijab- } \\
\text { wearing } \\
\text { Muslim } \\
\text { women in } \\
\text { Malaysia. }\end{array}$ & $\begin{array}{l}\text { Hijab as religious } \\
\text { obligation, Hijab as } \\
\text { fashion, Hijab } \\
\text { acceptance behavior. }\end{array}$ \\
\hline $\begin{array}{l}\text { Bachleda et } \\
\text { al [25] }\end{array}$ & 2014 & $\begin{array}{l}\text { Moroccan } \\
\text { Muslim } \\
\text { women. }\end{array}$ & $\begin{array}{l}\text { Religiosity, } \\
\text { subjective norm, } \\
\text { attitude, perceived } \\
\text { behavioral control, } \\
\text { intention and choice } \\
\text { of clothing }\end{array}$ \\
\hline $\begin{array}{l}\text { Farrag and } \\
\text { Hassan [26] }\end{array}$ & 2015 & $\begin{array}{l}\text { Egyptian } \\
\text { Muslim } \\
\text { students. } \\
\end{array}$ & $\begin{array}{l}\text { Religiosity, attitude } \\
\text { toward fashion. }\end{array}$ \\
\hline $\begin{array}{l}\text { Nayebzadeh } \\
\text { and Jalaly } \\
\text { [27] }\end{array}$ & 2014 & $\begin{array}{l}\text { Iranian } \\
\text { Muslim } \\
\text { females. }\end{array}$ & $\begin{array}{l}\text { Impulse buying } \\
\text { behavior, impulse } \\
\text { buying tendency, } \\
\text { emotion, self esteem, } \\
\text { life satisfaction. }\end{array}$ \\
\hline
\end{tabular}

${ }^{1}$ Year of publication

\section{Literature Review and Theoretical Framework}

\subsection{Hijab fashion}

Islam regulates every aspect of human's life including the way of clothing. The authentic connotation of "Hijab" is to cover, to screen, or to veil. The English phrase "scarf" and the Arabic expression "Hijab" have been applied jointly, but the Hijab has cultural milieus in many Muslim countries [16]. Generally Hijabs simply allude to the headscarves worn by Muslim women along with loose and modest dresses. However, Islamic dress code requires that both men and women have Hijab; men should cover their bodies from the naval to the knee; women should cover all the bodies except for the face and the hands up to the wirsts. Muslims, both women and men, should wear clothes that are modest and permitted by Islamic law (Sharia) i.e. loose or not tights, not skinny, not transparent, and not resemble that of the opposite gender. Men are not recommended to wear silk and gold because those resemble women's clothings. In addition, Hijab is not only about the clothes but also as a way of life including righteous deeds, behavior, attitude, moral conduct, and intention of the individuals. Hijab also connotes dropping the stare to the differing gender to circumvent the turpitudes of the eye and the heart.

\subsection{Hijab fashion supply chain}

A supply chain can be outlined as the set of activities that permit the transformation from the original raw materials to the eventual consumption of the final product, reaching out suppliers, manufacturers, distributors and other business players. The conventional supply chain scheme begins with raw material, inbound logistics, repository, manufacturing, depository, outbound logistics, and marketing, and it closes with sales and customer utility [23]. Hijab fashion supply chain starts with raw materials purchasing, Hijab manufacturing, Hijab marketing and ends with Hijab consumers [24].

Previous studies (for example, [8], [26]) have clearly identified the dimensions of Halal supply chain knowledge consisting of Halal animal feed, Halal slaughtering, and proper segregation and it hypothesized the direct relationships between them and consumer purchase intention. This made it easier to develop the framework further. Since this study focuses on Hijab fashion supply chain, it adapted these dimensions to knowledge of Halal purchasing, Halal manufacturing, and Halal marketing. Figure 3 indicates the conceptual framework generated in this study.

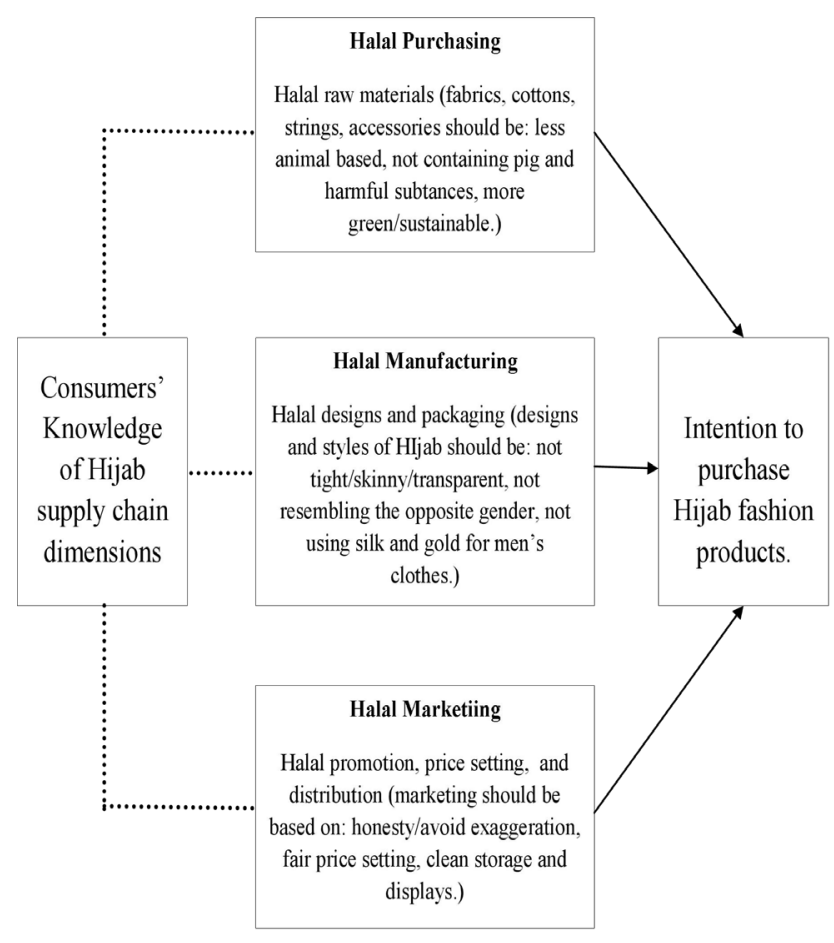

Figure 1. Theoretical framework of this study

\subsection{Consumers' knowledge}

Knowledge alludes to the truths, experiences or feelings renowned by an individual or a faction of people [27]. Knowledge performs an essential part in consumer behavior studies; it is one major factor that influences consumer's decision to purchase the products [28]. Every Muslim is commanded to wear Hijab clothings, which are the fashion products in accordance with Islamic dress code. Hijab fashion means fashion whose properties and processing techniques include raw materials, handling, 
the use of various methods from beginning to end, always in reference to Islamic law (Sharia). Prior research (for example, [3], [4], [7-10], [12]) found that there is significant relationship between consumers' knowledge of Halal products and their purchase intention. Hence, knowledge of Hijab fashion supply becomes an imperative part of Muslim consumers's intentions to purchase Hijab fashion.

\subsection{Halal purchasing}

Purchasing is an indispensable marketing field in prescribing the buyer-supplier connection, and there is capability to estblish a comprehensive ethical brand by unifying Islamic values and features like animal welfare, sustainability, health, less waste, satisfactory working circumstances [29]. In the Hijab fashion context, purchasing is an upstream activity based on suppliers value chain. The purchasing activities include procurement, planning, buying raw materials (e.g., fabrics or cottons, strings, accessories) and inbound logistics i.e. transportation of raw materials delivery to the Hijab company [24]. Halal purchasing for Hijab fashion refers to the raw materials bought by companies that should be permitted by Sharia (e.g., choosing Halal fabrics or textiles instead of non-Halal). Halal materials are green materials which are less animal based, more plant based and more sustainable. It is necesarry to ensure that raw materials used for Hijab are not containing haram (forbidden) stuffs such as the skin of pig or of animals that eat filth [30]. Sharia emphasizes that the animals need to be of a permissible species before being used for consumption both as foods and as clothings. Hence, if consumers recognized the specified requirements for Halal raw materials according to Sharia safety, hygienic, health, and sustainability factors, they would be more prompted to purchase Hijab fashion.

\subsection{Halal manufacturing}

Halal manufacturing refers to at least three aspects of production process. First, the cleanliness of equipments and physical environment are considered for Hijab production. Second, the designs and patterns of Hijab fashion are obliged to follow Sharia i.e. men's clothes should be designed to cover their bodies from the naval to the knee, women's clothes should cover all the bodies except for the face and the hands up to the wirsts, clothes should not resemble that of the opposite gender, clothes should be loose (not tight or skinny) and should not be transparent, and men's wardrobes should not be fashioned by gold and silk. Third, Halal packaging is applied for Hijab fashion products as one source of consumer information about the product quality. The packaging materials for Halal products, i.e., Hijab fashion should be manufactured from materials that are Halal [26]. Taking these procedures into account, it is testified that consumers who know about Halal manufacturing will be more potential to buy Hijab fashion.

\subsection{Halal marketing}

Marketing is a downstream activity based on consumers value chain in the Hijab fashion industry. Marketing activities includes promotion, price setting, choosing agents or distributors, and outbound logistics [24]. Halal marketing is not only practiced as business orientation but also applied as a way of life, e.g., righteous deeds, no ill intentions to harm, no corruption and fraud [25]. Promotion of Halal products, for example, should be based on honesty thus bombastic and false informations about products is definitely aginst the Sharia principles. Price should not be set too far-exceeding the product quality offered. Outbond logistics e.g. delivering orders should be done on time and in exact quality and quantity promised to the customers. In Islam, keeping the promises and satisfying the customers are parts of righteous deeds. In addition, cleanliness is also a part of faith. Thus, the cleanliness in distribution and retailing of Hijab fashion is also an essential element to be taken into account. Hijab industry should choose partners providing special facilities for Halal logistics to protect Hijab products, such as Halal transportation, Halal shipping, regular cleansing services for storages and displays. It is very admissible for Islamic product sellers to furnish an affirming atmosphere to its customers [31]. Hence, based on the assertions above, consumers amiably choose Hijab fashion if they have knowledge of how Hijab products are managed in the marketing and retailing stage. It is crucial that products that have been guaranteed of 'Halalness' in prior points in the supply chain preserve their value to the end.

\section{Conclusion and implication}

The fast expansion of the world's Muslim population in recent years results in a dramatic increase of demand for Halal products, especially Hijab fashion products. Halal issues on fashion are a main matter for consumers, manufacturers, and retailers. The upsurge of consumer knowledge regarding Halalness in the supply chain will assist them to purchase products that are Sharia compliant. Based on a complete literature review, this paper, genuinely, designs a conceptual framework. Due to the complex nature of the Hijab supply chain, we focused on the relationships that had the most prior studies support for testifying consumers' knowledge to their Halal purchase intention (for example, [8]). Thus, this conceptual framework brings together key variables in a single model with the purpose of recognizing how to establish a stronger relationship between knowledge dimensions of Hijab supply chain and purchase intention.

The vital contribution of this research is the development of a framework fostered by theory and studies that can be applied by suppliers, manufacturers, and marketers to grasp how to expand purchase intention by analyzing the consumers' knowledge of Hijab fashion supply chain. The implications of this research are that applying this framework can help the players in Hijab supply chain to show them which aspects of product knowledge improve interest in Hijab products, and 
eventually boost sales. Thus, this study is an invaluable source which should inform marketing plans and blueprints of companies involved in the Hijab business.

In the further investigation the authors will conduct an observed study to test the hypothesized dimensions and variables developed from this research. The authors have planned to carry out a quantitative research study to eventually examine and justify the conceptual framework and the hypothesized variables.

\section{Research Guidelines}

With this theoretical framework as a foundation, some research guidelines can be provided. The most preeminent recommendion for future studies would be to factually investigate the hypothesized links. Although this model is established from solid theoretical bases, a verifiable investigation with the hypothesized variables in a single model may prove to be an indispensable phase to further enhance this conceptual framework and improve our recognition of how to expand the relationships among knowledge dimensions of Hijab fashion supply chain and purchase intention. As mentioned before, the inquiry for future research can be: does consumers' knowledge of Hijab supply chains influence their purchase intention for Hijab fashion? The future study will, definitely, be the introductory exertion to verify the significance of relationship between consumers' each knowledge dimension as dependent variables and their purchase behavior as independent variable.

Furthermore, verifiable examinations could be conducted through a comparative study (for example, local vs. foreign Hijab brands, luxury vs. non-luxury Hijab products) in order to deliver a more thrifty framework appealing consumers' purchase intention in different conditions. Future studies could also factually investigate these links in different countries, because Hijab fashion has entered global market and adopt Islamic dress code and Halalness as international standards for Muslim consumers across globe. The evolvement of cross-cultural research may provide to easy perceiving the generality of the conceptual framework to different countries. Overall, we expect that this conceptual model accentuates the necessity for an original approach of bridging product knowledge and purchase intention in the Hijab supply chain, and offers a general basis for future empirical research. We anticipate that consecutively, those verifiable investigations of this framework will cultivate more practical advantages for suppliers, manufacturers, and marketers in the Hijab fashion industry.

\section{References}

1. T. Reuters, State of the Global Islamic Economy Report 2018/19 (Dubai: Thomson Reuters, 2019)

2. H.H. Tuu, S.O. Olsen, Asia Pac. J. of Marketing and Logis. 24, 78-101 (2012)

3. T. Nurhayati, H. Hendar, J. of Islamic Marketing (2019)
4. A. Haro, J. of Entrep.Business and Econ. 6, 78-91 (2018)

5. V. Briliana, N. Mursito, Asia Pac. Manag. Rev. 22, 176-184 (2017)

6. K. Maichum, S. Parichatnon, K. Peng, IRA-Int. J. of Manag. and Soc. Science 6, 354-364 (2017)

7. A. Reni, N.H. Ahmad, J. of Islamic Economics 8, 137-148 (2016)

8. F.A.M. Yusoff, R.N.R. Yusof, S.R. Hussi, Int. J. of Economics and Manag. 9, 155-172 (2015)

9. N.S.N.M Yunus, W.E.W Rashid, N.M. Ariffina, N.M. Rashida, Procedia - Soc. and Behav. Sciences, 130, 145-154 (2014)

10. H. Hamdan, Z.M. Issa, N. Abu, K. Jusoff, J. of Food Products Marketing 19, 54-61 (2013)

11. Y.A. Aziz, N.V. Chok, 3rd Int. Conf. on Business and Econ. Research Proc. Bandung (2012)

12. A. Mukhtar, M.M. Butt M M, J. of Islamic Marketing 3, 108-120 (2012)

13. F. Hasna, S.R.H. Hati, 2nd Int. Conf. on Financial Innovation and Economic Development 34 (Paris, 2017)

14. F. Fadhilla, Int. J. of Manag. and Appl. Science 3, 1620 (2017)

15. A. Zabeen, S. Shams, N. Sultana, Int. J. of Asian Soc. Science 7, 728-737 (2017)

16. S.H. Hassan, H.Harun, J. of Islamic Marketing 7, 476494 (2016)

17. H.T. Win, M.T. Jan, Amity J. of Marketing 1, 72-81 (2015)

18. L Nora, N.S. Minarti, Proc. The 2nd Int. Multidisciplinary Conf. November 15th, 135-148 (Jakarta, 2016)

19. F. Grine, M. Saeed, J. of Islamic Marketing 8, 430443 (2017)

20. C. Bachleda, N. Hamelin, O. Benachour, J. of Islamic Marketing 5, 210-226 (2014)

21. D.A. Farrag, M. Hassan, J. of Islamic Marketing 6, 95-108 (2015)

22. S. Nayebzadeh, M. Jalaly, J. of Islamic Marketing 5, 302-320 (2014)

23. M. Cooper, D. Lambert, J. Pagh, Int. J. of Logistics Manag. 8, 1-14 (1997)

24. M. Prasetyawati, W. Sudarwati, Proc. SNTI dan SATELIT (Malang) 4-6 October, 87-95 (2017)

25. J.M. Soon, M. Chandia, J.M. Regenstein, British Food J. 119, 39-51 (2017)

26. E.N. Omar, H.S. Jaafar, The IEEE Symp. on Business, Engine. and Indust. Appl (Langkawi, 2011)

27. A.A. Rahman, E. Asrarhaghighi, S.A. Rahman. J. of Islamic Marketing 6, 148-163 (2015)

28. K. Baharuddin, N.A. Kassim, S.K. Nordin, S.Z. Buyong, Int. J. of Academic Research in Business and Soc. Sciences 5, 170-178 (2015)

29. M. Ismaeel, K. Blaim, J. of Manag.Dev. 31, 10901100 (2012)

30. K. Bonne, W. Verbeke, Meat Science 79, 113-123 (2008)

31. H. Hashim, S.R. Hussin, N.N. Zainal, Int. J. of Economics and Manag. 8, 117-136 (2014) 